\title{
Inhibitory effect of retinoic acid on the development of immature porcine granulosa cells to mature cells
}

\section{M-A Hattori, K Takesue, N Nishida, Y Kato ${ }^{1}$ and $\mathbf{N}$ Fujihara}

Laboratory of Reproductive Physiology, Graduate School of Bioresource and Bioenvironmental Sciences, Kyushu University, Hakozaki, Fukuoka 812-8581, Japan

${ }^{1}$ Biosignal Research Center, Institute for Molecular and Cellular Regulation, Gunma University, Maebashi 371, Japan

(Requests for offprints should be addressed to M-A Hattori; Email: mhattori@agr.kyushu-u.ac.jp)

\begin{abstract}
The present study investigated the effect of retinoic acid (RA) on the differentiation of granulosa cells prepared from porcine ovaries. The granulosa cells were precultured for $15 \mathrm{~h}$, then cultured for $48 \mathrm{~h}$ with FSH and further treated for $24 \mathrm{~h}$ with $\mathrm{LH}$ in order to induce their transformation into luteal cells. After the cells had been exposed to $1 \mu \mathrm{M}$ retinoids (RA, retinal and retinol) for $87 \mathrm{~h}$, analysis of the LH receptor mRNA expression, an indicator of granulosa cell differentiation, was carried out by using semiquantitative RT-PCR. The results showed that there was a decrease in $\mathrm{LH}$ receptor mRNA levels, and that RA had a more potent effect on these levels than the other two retinoids. When cells were exposed to RA in the immature stage (before the addition of FSH) or the early stage of development (0-24 h after the addition of FSH), expression of $\mathrm{LH}$ receptor $\mathrm{mRNA}$ was greatly

diminished. When the immature cells were cultured for $15 \mathrm{~h}$ with RA, then washed and cultured for $48 \mathrm{~h}$ with FSH and for $24 \mathrm{~h}$ with $\mathrm{LH}$, the expression of $\mathrm{LH}$ receptor mRNA was not reversed. In the differentiated cells ( $24 \mathrm{~h}$ after the addition of $\mathrm{FSH}$ ), however, RA no longer had any inhibitory effect. When the immature cells were exposed to RA, FSH-induced expression of c-fos mRNA was markedly decreased. In contrast, expression of c-jun and activating transcription factor-4 mRNAs remained constant. However, the expression of c-fos mRNA was not decreased by forskolin. The results indicate that RA is a potent inhibitor in the immature stage of porcine granulosa cell differentiation, probably through decreased expression of FSH receptor, but that RA does not inhibit differentiation in the mature stage of the cells. Fournal of Molecular Endocrinology (2000) 25, 53-61
\end{abstract}

\section{INTRODUCTION}

Retinoic acid (RA) regulates cellular functions by binding to intracellular RA receptor (RAR) or retinoid $\mathrm{X}$ receptor (RXR). These two retinoid receptor families act via formation of either RAR-RXR heterodimer or RXR-RXR homodimer, both of which regulate the expression of RA target genes (Mangelsdorf \& Evans 1995). RA has been shown to be essential for the growth and differentiation of many types of cells. Numerous studies have reported that RA induces terminal differentiation of many cell types, including P19 embryonal carcinoma (Paterno et al. 1997), F9 murine tetracarcinoma cells (Faria et al. 1998), and HL-60 human myeloblastic leukemia cells (Yen et al. 1999). However, the nature of the proliferation and differentiation responses elicited by RA are depen- dent on the cell type. Thus, the differentiation of 3T3-L1 preadipocytes is inhibited in an early stage by RA (Chawla \& Lazar 1994), whereas that in Ob17 and rat preadipocytes is strongly enhanced by RA (Safonova et al. 1994). In rat ovarian granulosa cells, retinoids have been reported to exert a biphasic effect on luteinizing hormone (LH) receptor induction, as revealed by a ligand-binding assay (Bagavandoss \& Midgley 1988), suggesting that the response of granulosa cells to RA depends upon the stage of differentiation.

The expression of several proto-oncogenes has been associated with the proliferation and differentiation phases in many cell types. Transient or constitutive expression of such transcription factors as proto-oncogenes (c-fos, c-jun, c-myc) and the cAMP response element-binding protein (CREB) or activating transcription factor-4 (ATF-4) family 


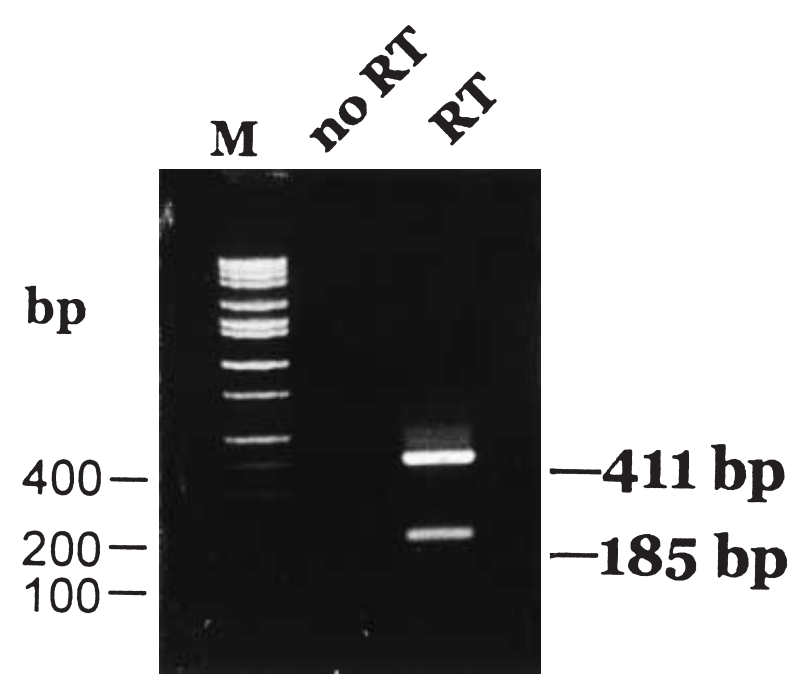

FIGURE 1. RT-PCR analysis of $\mathrm{LH}$ receptor mRNA expression in cultured granulosa cells. Cells were incubated for $15 \mathrm{~h}$, cultured for $48 \mathrm{~h}$ with FSH $(10 \mathrm{ng} / \mathrm{ml})$, and stimulated for $24 \mathrm{~h}$ with $\mathrm{LH}(100 \mathrm{ng} / \mathrm{ml})$; thereafter, RNA was extracted and reverse transcribed into cDNA, and samples were subjected to PCR amplification with primers for porcine $\mathrm{LH}$ receptor $\mathrm{cDNA}$. The products were not detected in the RNA samples without RT reaction (no RT). M, DNA mol wt marker. is promoted by protein kinase $\mathrm{C}$ and/or protein kinase A (Doucet et al. 1990, Sheng \& Greenberg 1990). Activation of the RA nuclear receptor could act as a molecular switch for a cascade of sequential changes in gene expression involving several nuclear factors (Griep \& DeLuca 1986, Thiele et al. 1988, Oberg \& Carpenter 1989, Schule et al. 1991). The major actions of such transcription factors are related to the transcription of several late gene responses that are regulators of cell differentiation.

Differentiation of ovarian granulosa cells involves follicle-stimulating hormone (FSH)-stimulated transformation of immature into mature cells. A prominent biochemical event in this differentiation is the expression of $\mathrm{LH}$ receptor by the cAMP signaling pathway (Hsueh et al. 1989). In a study using rat granulosa cells, RA inhibited LH receptor induction in a dose-dependent manner, and this inhibition was associated with a decrease in cAMP and progesterone levels (Bagavandoss \& Midgley 1988). Despite these studies, however, the effects of RA on granulosa cell differentiation have not been adequately characterized. In the present study, we used semiquantitative reverse transcriptionpolymerase chain reaction ( $\mathrm{RT}-\mathrm{PCR}$ ) to determine whether RA exposure would induce any changes in

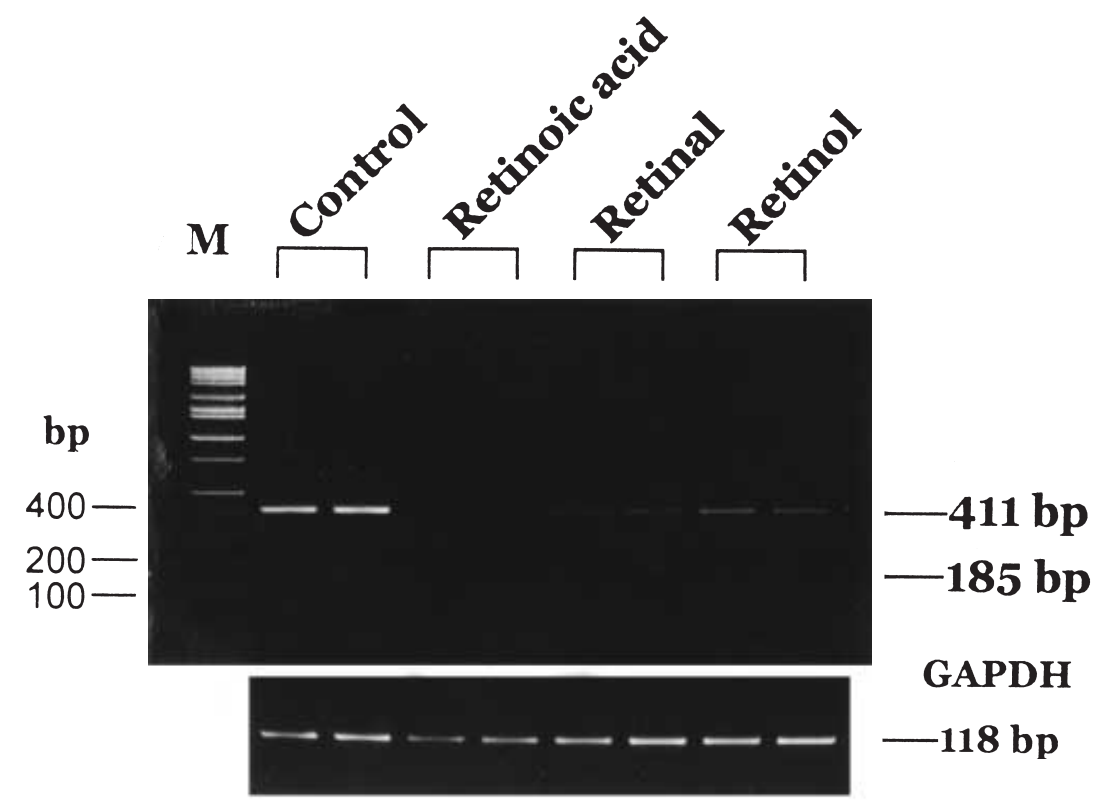

FIGURE 2. Inhibition of $\mathrm{LH}$ receptor mRNA levels by retinoid derivatives. Cells were incubated for $15 \mathrm{~h}$ in the presence or absence of $1 \mu \mathrm{M}$ retinoids, cultured for $48 \mathrm{~h}$ with FSH $(10 \mathrm{ng} / \mathrm{ml})$ in the presence or absence of retinoids, and stimulated for $24 \mathrm{~h}$ with $\mathrm{LH}(100 \mathrm{ng} / \mathrm{ml})$. Then, RNA was extracted and reverse transcribed into cDNA, and samples were subjected to PCR amplification with primers for porcine LH receptor cDNA. Similar results were obtained in two different mRNA preparations. M, DNA mol wt marker. 
the expression of $\mathrm{LH}$ receptor $\mathrm{mRNA}$ and the transcription factors c-fos, c-jun and ATF-4 in association with the differentiation of porcine granulosa cells.

\section{MATERIALS AND METHODS}

\section{Materials}

Ovine FSH (NIDDK-oFSH-20) and LH (NIDDK-oLH-26) were supplied by Dr A F Parlow (Harbor-UCLA Medical Center, Torrance, CA, USA). All trans-retinoids (RA, retinal and retinol) were from Sigma Chemicals (St Louis, MO, USA); Ham's F-10 and Dulbecco's minimum essential medium (DMEM) were from Gibco Laboratories (Grand Island, NY, USA); ISOGEN was from Wako (Osaka, Japan); the T-primed first-strand kit was from Amersham Pharmacia Biotech (Tokyo, Japan); and AmpliTaq Gold polymerase was from Perkin-Elmer (Norwalk, CT, USA). All the other chemicals used were of reagent grade and obtained from commercial sources.

\section{Cell culture}

Porcine ovaries were obtained at a local slaughterhouse. Granulosa cells were prepared from medium-sized (1-4 $\mathrm{mm}$ diameter) follicles by aspirating with a 20 gauge needle and then filtering through a fine stainless steel mesh. They were treated with $50 \mu \mathrm{g}$ DNase $\mathrm{I} / \mathrm{ml}$ at $37^{\circ} \mathrm{C}$ for $5 \mathrm{~min}$, and washed with Ham's F-10 and DMEM (1:1) supplemented with $10 \mathrm{mM}$ HEPES, $50 \mu \mathrm{g}$ gentamycin $/ \mathrm{ml}$, and $20 \mathrm{U}$ nystatin $/ \mathrm{ml}$ (Mondschein et al. 1990). Cell viability was determined to be $>95 \%$ by trypan blue exclusion. Cells were seeded at $2 \times 10^{5} /$ well in 48 -well plates coated with fibronectin (Falcon; Becton-Dickinson, Oxnard, CA, USA) with $100 \mathrm{nM}$ androstenedione, $110 \mathrm{nM}$ hydrocortisone, $1 \mu \mathrm{g}$ insulin $/ \mathrm{ml}, 5 \mu \mathrm{g}$ transferrin $/ \mathrm{ml}$ and $0 \cdot 1 \%(\mathrm{w} / \mathrm{v})$ bovine serum albumin at $39^{\circ} \mathrm{C}$ in a humidified atmosphere of $95 \%$ air and $5 \%$ $\mathrm{CO}_{2}$.

\section{Hormonal treatment of cultured granulosa cells}

After culturing the granulosa cells for $15 \mathrm{~h}$ with various concentrations $(10,100$ and $1000 \mathrm{nM})$ of retinoids, $10 \mathrm{ng} \mathrm{FSH} / \mathrm{ml}$ was added to the cultures in the presence of retinoids (culture $0 \mathrm{~h}$ ). The cells were matured by culturing for an additional $48 \mathrm{~h}$, and then they were washed with culture medium

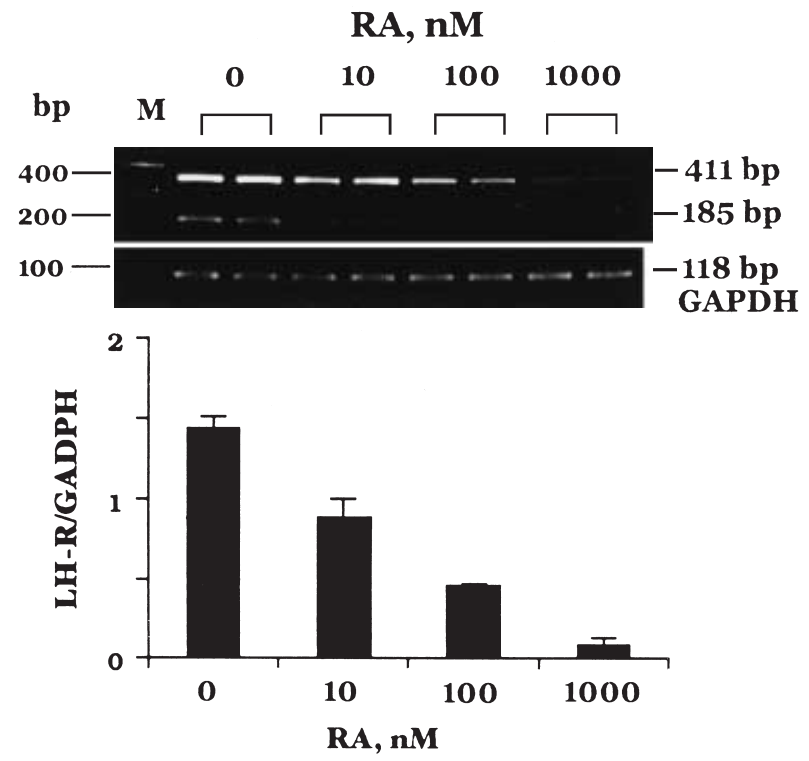

FIGURE 3. Dose-dependent inhibition of LH receptor (LH-R) mRNA levels by RA. Cells were incubated for $15 \mathrm{~h}$ in the presence or absence of RA $(0 \cdot 01,0 \cdot 1$ and $1 \mu \mathrm{M})$, cultured for $48 \mathrm{~h}$ with FSH $(10 \mathrm{ng} / \mathrm{ml})$ in the presence or absence of RA, and stimulated for $24 \mathrm{~h}$ with $\mathrm{LH}(100 \mathrm{ng} / \mathrm{ml})$. Then, RNA was extracted and reverse transcribed into cDNA, and samples were subjected to PCR amplification with primers for porcine $\mathrm{LH}$ receptor cDNA. Similar results were obtained in two different mRNA preparations. The data are normalized for GADPH RT-PCR product levels in each sample and presented as the means \pm S.E. M, DNA mol wt marker.

and exposed to $100 \mathrm{ng} \mathrm{LH} / \mathrm{ml}$. In some experiments, RA was added to the culture at the indicated times.

\section{RNA isolation and CDNA preparation}

After removal of the media, $0.5 \mathrm{ml}$ ISOGEN was added to each well to dissolve the cells. Each resulting solution was transferred to a microtube, extracted with $0 \cdot 1 \mathrm{ml}$ chloroform and centrifuged at $12000 \mathrm{~g}$ for $15 \mathrm{~min}$. The aqueous phase was collected and precipitated with $0.2 \mathrm{ml}$ isopropylalcohol at room temperature, and the precipitate was washed with $75 \%(\mathrm{v} / \mathrm{v})$ ethanol. After drying, the recovered RNA was dissolved in $20 \mu \mathrm{l}$ diethylpyrocarbonate-treated water. Reverse transcription was performed using a T-primed firststrand kit as follows. Samples of $10 \mu \mathrm{l}$ RNA mixed with the reagent were incubated at $45^{\circ} \mathrm{C}$ for $1 \mathrm{~h}$, diethylpyrocarbonate-treated water was added to each tube (final volume, $50 \mu \mathrm{l}$ ) and the mixture was heated at $70{ }^{\circ} \mathrm{C}$ for $5 \mathrm{~min}$. 


\section{Time of RA addition, $h$}

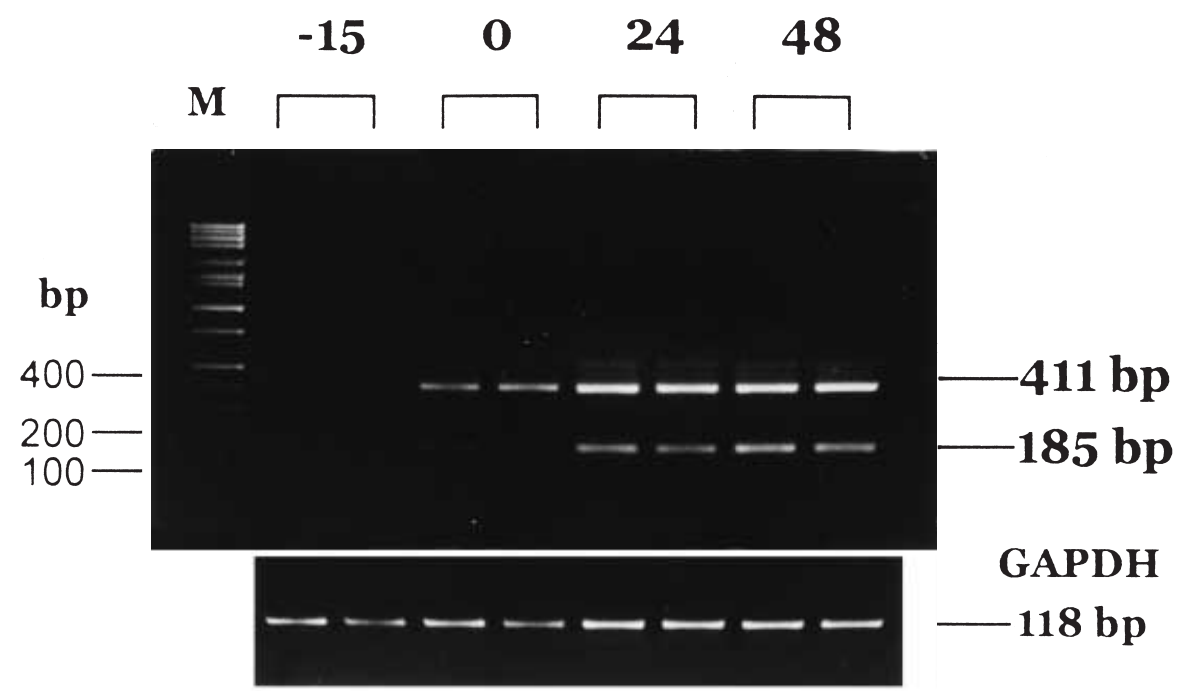

FIGURE 4. Effect of RA administration at different times on $\mathrm{LH}$ receptor mRNA levels. Cells were incubated for $15 \mathrm{~h}$, cultured for $48 \mathrm{~h}$ with FSH $(10 \mathrm{ng} / \mathrm{ml})$, and stimulated for $24 \mathrm{~h}$ with $\mathrm{LH}(100 \mathrm{ng} / \mathrm{ml})$. RA (final concentration: $1 \mu \mathrm{M}$ ) was added to cultures at different times $(-15,0,24$ and $48 \mathrm{~h}$ after the addition of FSH). RNA was then extracted and reverse transcribed into cDNA, and samples were subjected to PCR amplification with primers for porcine $\mathrm{LH}$ receptor $\mathrm{cDNA}$. The results were obtained from two independent RT-PCR experiments performed for two different mRNA preparations. M, DNA mol wt marker.

\section{Analysis of granulosa cells for mRNA of $\mathrm{LH}$ receptor and transcription factors using RT-PCR}

After an initial denaturation step $\left(95^{\circ} \mathrm{C}\right.$ for $\left.10 \mathrm{~min}\right)$, amplification of each cDNA (1-3 $\mu$ l RT template) was performed in $10 \mu \mathrm{l} 1 \times$ PCR buffer, $0 \cdot 2 \mathrm{mM}$ dNTPs, $0 \cdot 25 \mathrm{U}$ AmpliTaq Gold polymerase, and $0 \cdot 2 \mu \mathrm{M}$ each of the synthetic primers. A pair of primers were selected for dectecting the mRNAs of porcine LH receptor isoforms (Loosfelt et al. 1989). The sense primer was a 25 mer oligonucleotide corresponding to positions 861-885 (5'CCAATCTCC'TAGATGCCACATTGAC-3') on the porcine $\mathrm{LH}$ receptor mRNA. The antisense primer was a 23 mer oligonucleotide corresponding to positions 1981-1959 (5'-GCTCAGCAACAG AAAGAAATCCC-3'). The predicted sizes of $\mathrm{LH}$ receptor RT-PCR products were $1114 \mathrm{bp}$, $855 \mathrm{bp}, 411 \mathrm{bp}$ and $185 \mathrm{bp}$. However, two large sizes (1114 bp, $855 \mathrm{bp}$ ) were not detected. The amplification step for porcine $\mathrm{LH}$ receptor consisted of 30-34 cycles under a thermal profile of $95{ }^{\circ} \mathrm{C}$ for $30 \mathrm{~s}$ (denaturation), $54{ }^{\circ} \mathrm{C}$ for $30 \mathrm{~s}$ (annealing), and $72{ }^{\circ} \mathrm{C}$ for $2 \mathrm{~min}$ (synthesis). The RT-PCR products of $411 \mathrm{bp}$ and $185 \mathrm{bp}$ linearly increased from 30 to 35 cycles under this condition (data not shown).

Amplification of porcine c-fos, c-jun and ATF-4 consisted of 34 cycles under the same thermal schedule using the specific primer sets of c-fos (sense, 5'-CCGAAGGGAAAGGAATAAGATG G-3'; antisense, 5'-TCGGTGTCTGTAGAGAA GACC-3') (Chung et al. 1996), c-jun (sense, 5'CCGAAGGGAAAGGAATAAGATGG-3'; antisense, 5'-ACGTTGACGACGCAATCGTAC-3') (Chung et al. 1996), and ATF-4 (sense, 5'GCAGAGCAGGAGGCCCTCACTG-3'; antisense, 5'-ACGTTGACGACGCAATCGTAC-3') (Kato et al. 1999). The predicted sizes of c-fos, c-jun and ATF-4 PCR products were $232 \mathrm{bp}$, $179 \mathrm{bp}$ and $216 \mathrm{bp}$ respectively. Gyceraldehyde-3phosphate dehydrogenase (GAPDH) was used as an internal amplification control (sense, 5'-TCCTGT CCTGCACCACCAACTGCTTAG-3'; antisense, 5'-GTAGGTGTCAGAAGACTCACCGTC-3') to generate a PCR product of $118 \mathrm{bp}$. The amplified products were resolved by $2 \%$ agarose gel electrophoresis, stained with ethidium bromide, and photographed under u.v. light. The intensities of 


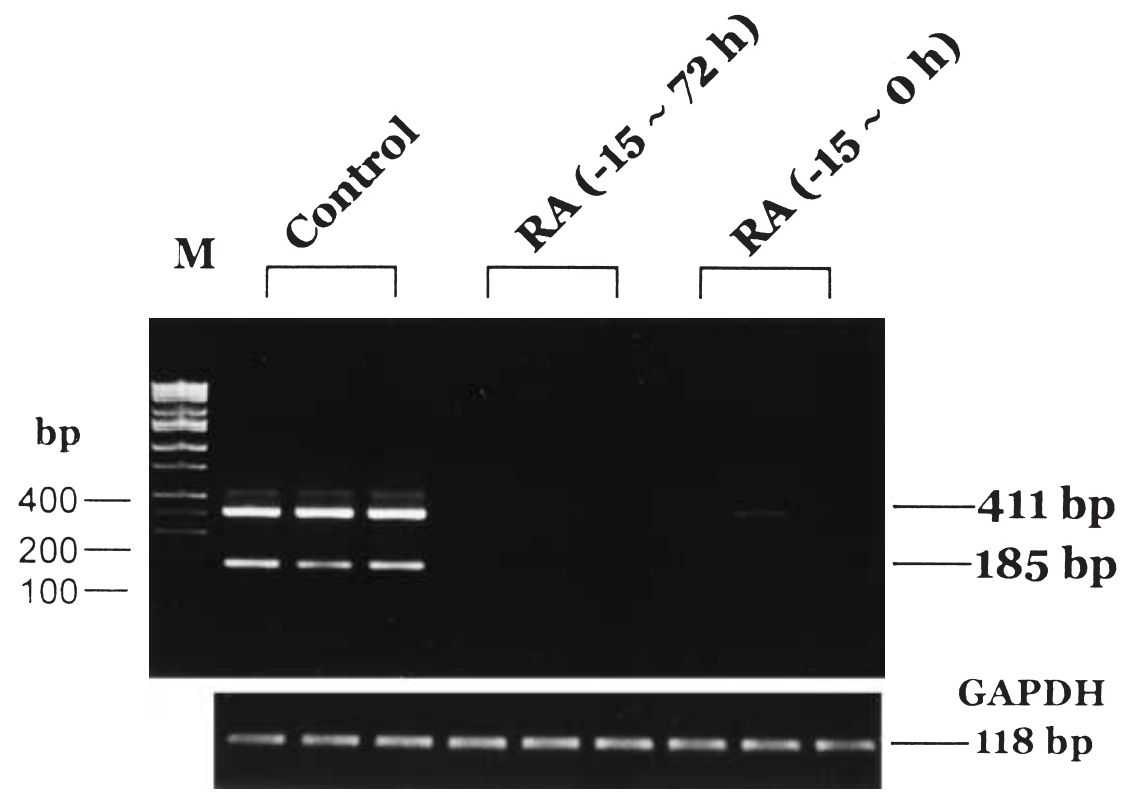

FIGURE 5. Maximum induction of RA inhibition in the immature granulosa cells. Cells were incubated for $15 \mathrm{~h}$ in the presence or absence of $1 \mu \mathrm{M}$ RA, then cells were washed twice and cultured for $48 \mathrm{~h}$ with FSH $(10 \mathrm{ng} / \mathrm{ml})$ in the presence or absence of $1 \mu \mathrm{M}$ RA, then stimulated for $24 \mathrm{~h}$ with $\mathrm{LH}(100 \mathrm{ng} / \mathrm{ml})$. RNA was extracted and reverse transcribed into cDNA, and samples were subjected to PCR amplification with primers for porcine LH receptor cDNA. The results were obtained from three independent RT-PCR experiments performed for three different mRNA preparations.

the bands were quantified as a reference gene of GAPDH using a densitometry program (NIH Image Version 1.58).

\section{RESULTS}

\section{Expression of $\mathrm{LH}$ receptor mRNA during luteinization}

The induction of $\mathrm{LH}$ receptor mRNA was determined as an indicator of differentiation and luteinization. After culturing the granulosa cells for $15 \mathrm{~h}, \mathrm{FSH}$ was added $(0 \mathrm{~h})$ and the cells were cultured for an additional $48 \mathrm{~h}$. LH was then added and, after culturing for a final $24 \mathrm{~h}$, total RNA was isolated. Although four $\mathrm{LH}$ receptor isoforms are expressed in the porcine ovary (Loosfelt et al. 1989), only two receptor isoforms were detected in the primer sets, one with a product size of $411 \mathrm{bp}$ and one of $185 \mathrm{bp}$ (Fig. 1). These isoforms were not amplified in the RNA sample without the RT reaction. Thus, $\mathrm{LH}$ receptor $\mathrm{mRNA}$ was expressed during luteinization induced by LH.

\section{Retinoid suppression of $\mathrm{LH}$ receptor mRNA expression}

We next examined the effect of retinoids on the expression of porcine $\mathrm{LH}$ receptor $\mathrm{mRNA}$ during luteinization of the granulosa cells. The granulosa cells were cultured for $15 \mathrm{~h}$ in the presence of $1 \mu \mathrm{M}$ $\mathrm{RA}$, retinal or retinol, and then FSH was added to the cultures. After treatment with FSH for $48 \mathrm{~h}$, the cells were washed and exposed to $\mathrm{LH}$ in the presence or absence of retinoids. A maximal level of $\mathrm{LH}$ receptor PCR products was observed $24 \mathrm{~h}$ after LH stimulation, and the level decreased thereafter. RA decreased the expression of $\mathrm{LH}$ receptor mRNA (Fig. 2). The precursors of RA, retinal and retinol also inhibited receptor expression. RA decreased receptor mRNA expression in a dosedependent manner, showing a maximum effect at $1 \mu \mathrm{M}$ (Fig. 3).

\section{Maximum inhibitory effect of RA on the immature cells}

In order to further examine the inhibitory action of RA, it was added to cultures at various times 
$(-15,0,24$ or $48 \mathrm{~h})$, and FSH was added at $0 \mathrm{~h}$. After washing the cells at $48 \mathrm{~h}$, the cells were treated for $24 \mathrm{~h}$ with $\mathrm{LH}$ in the presence or absence of RA. The inhibitory action of RA was clearly observed at $-15 \mathrm{~h}$ and $0 \mathrm{~h}$, whereas it was not observed at $24 \mathrm{~h}$ and $48 \mathrm{~h}$ (Fig. 4). Thus, the inhibitory effect of RA may be dependent upon the progress of differentiation.

\section{Effect of RA on immature cells}

To test whether the inhibitory action of RA is more effective in immature than in mature cells, granulosa cells were exposed to RA only before FSH stimulation. The cells were cultured for $15 \mathrm{~h}$ in the presence of RA, then washed twice and cultured for $48 \mathrm{~h}$ with FSH and for $24 \mathrm{~h}$ with LH. As shown in Fig. 5, expression of $\mathrm{LH}$ receptor mRNA was suppressed by the initial 15-h exposure to RA, and was not further suppressed thereafter. Thus, the immature granulosa cells were much more sensitive to the inhibitory action of RA than were the mature cells.

\section{Suppression of FSH-stimulated expression of c-fos mRNA in RA-treated cells}

After treatment of the granulosa cells with RA, $\mathrm{FSH}$-induced expression of the c-fos, c-jun and ATF-4 mRNAs was tested. A maximal expression of c-fos was observed $30 \mathrm{~min}$ after exposure to FSH, whereas c-jun and ATF-4 were constitutively expressed (data not shown). Figure 6 shows the effect of RA on expression of the c-fos, c-jun and ATF-4 mRNAs. When the cells were exposed to RA for $15 \mathrm{~h}, \mathrm{FSH}$-induced expression of c-fos mRNA was markedly decreased. In contrast, expression of the c-jun and ATF-4 mRNAs remained constant.

\section{Forskolin-induced expression of c-fos mRNA in RA-treated cells}

After treatment of the granulosa cells with RA for $15 \mathrm{~h}$, expression of c-fos mRNA was tested by $10 \mu \mathrm{M}$ forskolin. In contrast to $\mathrm{FSH}$ stimulation, forskolin induced the expression of $\mathrm{c}$-fos mRNA (Fig. 7).

\section{DISCUSSION}

In the present study, RA has been shown to inhibit the differentiation of granulosa cells prepared from porcine ovaries. RA inhibition has previously been reported to occur in granulosa cells in association
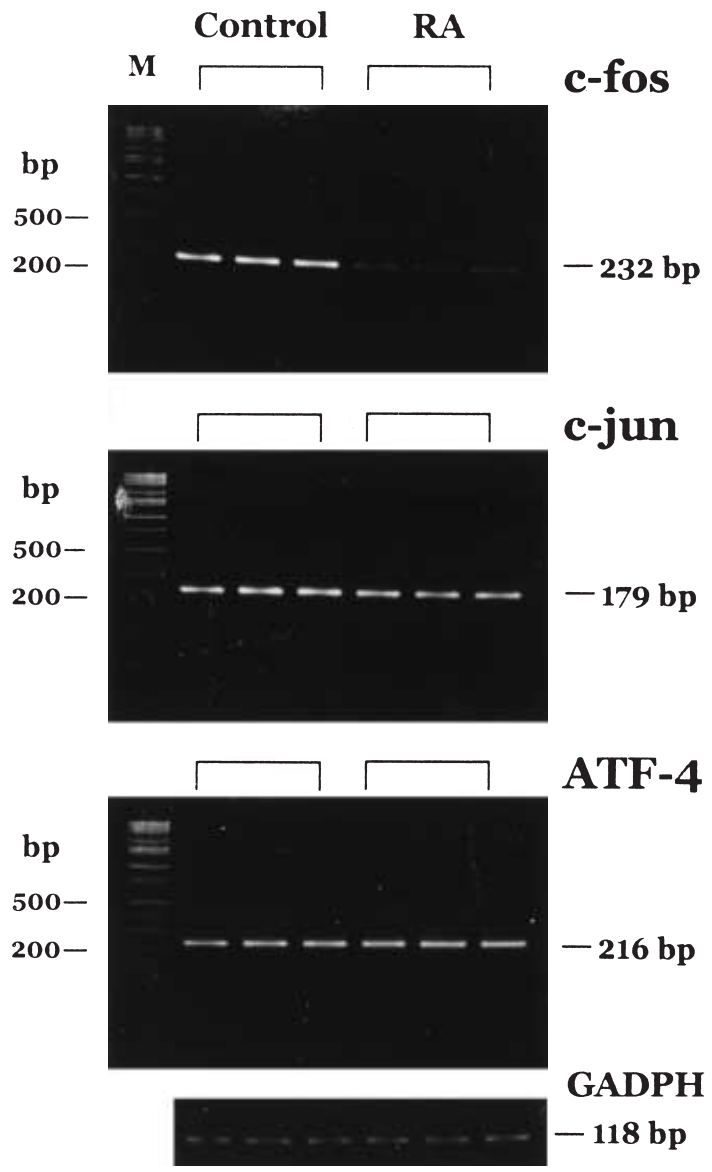

FIGURE 6. Effect of RA pretreatment on FSH-induced levels of transcription factor c-fos, c-jun and ATF-4 mRNAs. Cells were incubated for $15 \mathrm{~h}$ in the presence or absence of $1 \mu \mathrm{M} \mathrm{RA}$, then cells were washed twice and treated for $30 \mathrm{~min}$ with $\mathrm{FSH}(10 \mathrm{ng} / \mathrm{ml})$; thereafter, RNA was extracted and reverse transcribed into cDNA, and samples were subjected to PCR amplification with primers for porcine c-fos, c-jun and ATF-4. The results were obtained from three independent RT-PCR experiments performed for three different mRNA preparations. M, DNA mol wt marker.

with FSH-induced LH/human chorionic gonadotropin receptor induction as well as cAMP and progesterone accumulation (Bagavandoss \& Midgley 1988). In this work, RA clearly suppressed the expression of $\mathrm{LH}$ receptor $\mathrm{mRNA}$ in granulosa cells matured by FSH, as revealed by RT-PCR analysis. To ascertain the granulosa cell differentiation stage at which the inhibition of RA was maximal, RA was added at different time-points during culturing. The inhibitory effect of RA on receptor mRNA expression was time-dependent and much more pronounced in immature than in mature cells. After immature cells were exposed to RA for an initial 


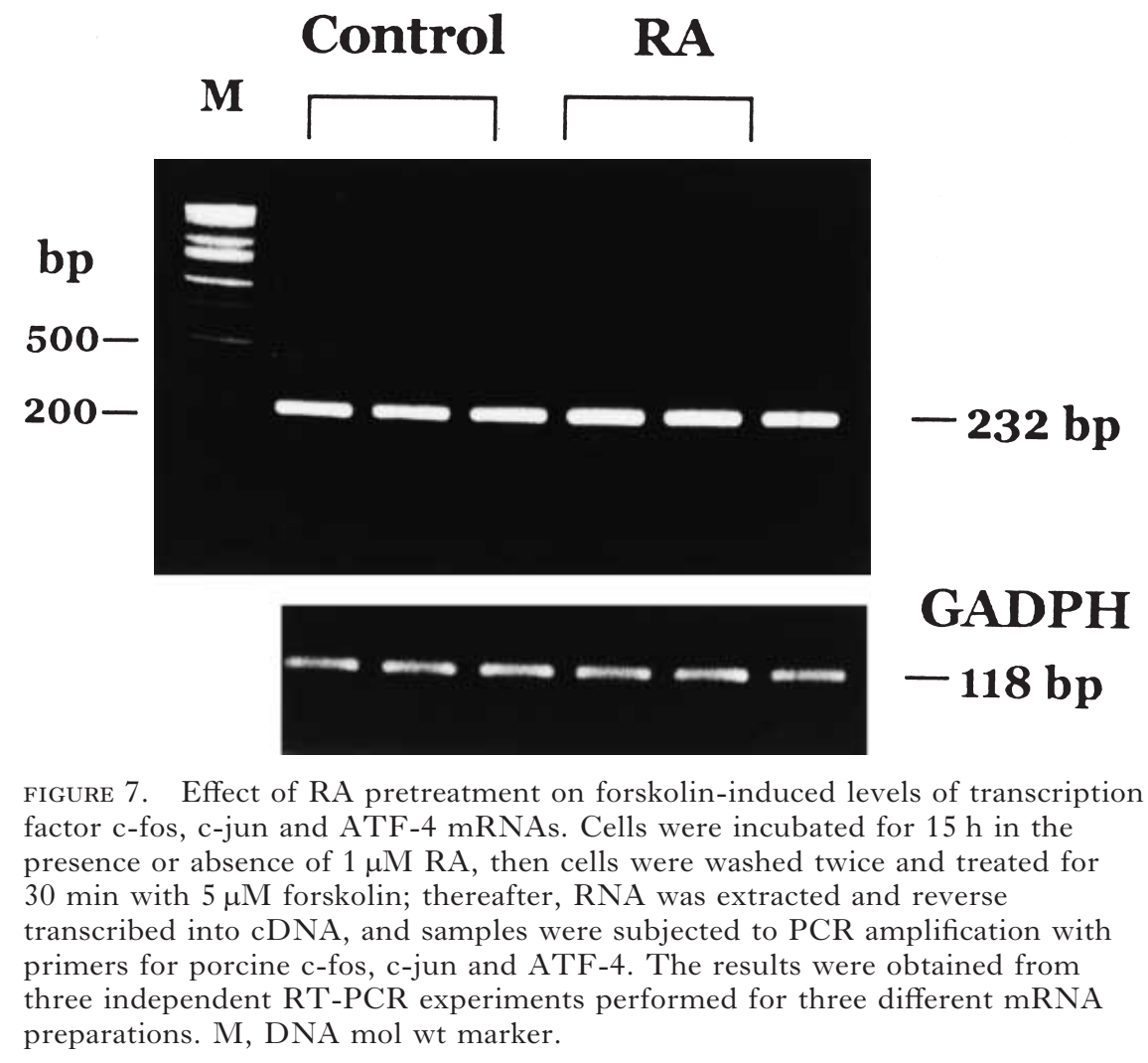

$15 \mathrm{~h}$, washed twice, cultured for $48 \mathrm{~h}$ with $\mathrm{FSH}$, and stimulated with LH for $24 \mathrm{~h}$, their expression of LH receptor mRNA was markedly decreased. These data indicate that RA acts as an inhibitory factor in the immature stage of granulosa cells, and that FSH cannot initiate the differentiation of RA-treated cells. After the initiation of the differentiation signal by FSH, however, RA was less effective. These results indicate that RA blocks the development of immature, but not mature, granulosa cells.

RA is known to cause G0 arrest in S91 melanoma cells (Spanjaard et al. 1997), F9 murine teratocarcinoma cells (Faria et al. 1998), and HL-60 human myeloblastic leukemia cells (Yen et al. 1999). In contrast, RA causes cell differentiation in PCC7-Mz1 embryonic carcinoma cells (Herget et al. 1998), P19 mouse embryonic carcinoma cells (Jho et al. 1997) and porcine preadipocytes (Suryawan \& Hu 1997). Thus, the differentiation response elicited by RA may depend on cell type. Further, RA alone cannot induce the differentiation of rat granulosa cells (Bagavandoss \& Midgley 1988). Retinoids have been shown to inhibit FSH-stimulated cAMP formation and aromatase activation in cultured rat Sertoli cells (Galdieri \&
Nistico 1994) and to inhibit expression of FSH receptor mRNA in cultured rat granulosa cells (Minegishi et al. 1996). The action of FSH is exerted through the FSH receptor, resulting in development of both Sertoli and granulosa cells. Expression of FSH receptor $\mathrm{mRNA}$ is maximally induced after 24-h incubation with FSH (Minegishi et al. 1996). In the present study, simultaneous addition of RA and FSH caused a decrease in the LH receptor $\mathrm{mRNA}$ level, although this decreased level was still higher than the level of $\mathrm{LH}$ receptor mRNA after RA pretreatment for $15 \mathrm{~h}$. After 24-h incubation with FSH, the addition of RA did not decrease LH receptor $\mathrm{mRNA}$ level, showing that RA is effective until $24 \mathrm{~h}$ after FSH stimulation. Taken together, these results indicate that the response of granulosa cells to RA may depend on the stage of differentiation. Thus, cells may be RA-sensitive over a period beginning with the immature stage or onset of differentiation and ending 24 h later.

Protein kinase $\mathrm{A}$ is involved in the regulation of c-fos transcription through a well-characterized mechanism of phosphorylation of the dimeric transcription factor, CREB or ATF-4 (Meyer \& Habener 1993). RA has been reported to act as a 
negative regulator of activator protein (AP)-1responsive genes (Schule et al. 1991). In addition, the primary response gene products encode proteins that form hetero- or homodimeric AP-1 factors, i.e. jun/fos or jun/jun, which are involved in activation or repression of several late response genes, depending on their composition. Therefore, expression of these transcription factor mRNAs was determined by using RT-PCR. RA significantly decreased the expression of c-fos mRNA induced by FSH stimulation, whereas c-jun and ATF-4 were not influenced by RA. Alteration of c-fos mRNA expression may result in the decreased level of $\mathrm{LH}$ receptor mRNA, because the major actions of these transcription factor gene products are related to the transcription of several late gene responses that are associated with cell proliferation or differentiation. However, there has been no report of the presence of an AP-1 site in the promoter domain of the $\mathrm{LH}$ receptor gene, suggesting that AP-1 factors do not bind directly to the $\mathrm{LH}$ receptor gene. The finding that $\mathrm{c}$-fos mRNA expression was inhibited by RA may indicate that the FSH receptor was not activated. Actually, forskolin could increase c-fos mRNA level in the RA-treated cells. This result suggests that the signaling pathway from the action of cAMP to expression of c-fos mRNA is at least normally maintained in the RA-treated cells.

In conclusion, RA had a profound effect on the differentiation of granulosa cells in the present study, provided that cells were exposed to RA in the immature rather than in the mature stage, through inhibition of FSH-induced expression of c-fos and/or expression of FSH receptor. It seems likely that RA does not directly inhibit the expression of c-fos mRNA, at least in granulosa cells.

\section{ACKNOWLEDGEMENTS}

We are grateful to Dr A F Parlow for the supply of ovine FSH. This study was supported by a Grant-in-Aid for Scientific Research (B) No. 09460139 from the Japanese Ministry of Education, Science and Culture (to M-A H) and the Mishyma Kaiun Memorial Foundation.

\section{REFERENCES}

Bagavandoss P \& Midgley AR Jr 1988 Biphasic action of retinoids on gonadotropin receptor induction in rat granulosa cells in vitro. Life Sciences 43 1607-1614.

Chawla A \& Lazar M 1994 Peroxisome proliferator and retinoid signaling pathways coregulate preadipocyte phenotype and survival. Proceedings of the National Academy of Sciences of the USA 91 1786-1790.
Chung H-O, Kato T \& Kato Y 1996 Molecular cloning of c-jun and c-fos cDNAs from porcine anterior pituitary and their involvement in gonadotropin-releasing hormone stimulation. Molecular and Cellular Endocrinology 119 $75-82$.

Doucet JP, Squinto SP \& Bazan NG 1990 Fos-jun and the primary genomic response in the nervous system. Possible physiological role and pathophysiological significance. Molecular Neurobiology 4 27-55.

Faria TN, LaRosa GJ, Wilen E, Liao J \& Gudas LJ 1998 Characterization of genes which exhibit reduced expression during the retinoic acid-induced differentiation of $\mathrm{F} 9$ teratocarcinoma cells: involvement of cyclin D3 in RA-mediated growth arrest. Molecular and Cellular Endocrinology 143 155-166.

Galdieri M \& Nistico L 1994 Retinoids regulate gonadotropin action in cultured rat Sertoli cells. Biology of Reproduction $\mathbf{5 0}$ 171-177.

Griep AE \& DeLuca HF 1986 Decreased c-myc expression is an early event in retinoic acid-induced differentiation of $\mathrm{F} 9$ teratocarcinoma cells. PNAS 83 5539-5543.

Herget T, Specht H, Esdar C, Oehrlein SA \& Maelicke A 1998 Retinoic acid induces apoptosis-associated neural differentiation of a murine teratocarcinoma cell line. Fournal of Neurochemistry 70 47-58.

Hsueh AJW, Bicsak TA, Jia X-C, Dahl KD, Fauser BCJM, Galway AB, Czekala N, Pavlou SN, Papkoff H, Keene J \& Boime I 1989 Granulosa cells as hormone target: the role of biologically active follicle-stimulating hormone in reproduction. Recent Progress in Hormone Research $\mathbf{4 5}$ 209-273.

Jho EH, Davis RJ \& Malbon CC 1997 c-Jun amino-terminal kinase is regulated by Galpha12/Galpha13 and obligate for differentiation of P19 embryonal carcinoma cells by retinoic acid. Fournal of Biological Chemistry 272 $24468-24474$.

Kato Y, Koike Y, Ogawa S, Tomizawa K, Hosaka K, Tanaka S \& Kato T 1999 Presence of activating transcription factor 4 (ATF4) in porcine anterior pituitary. Molecular and Cellular Endocrinology 154 151-159.

Loosfelt H, Misrahi M, Atger M, Salesse R, Vu Hai-Luu Thi MT, Jolivet A, Guiochon-Mantel A, Sar S, Jallal B, Garnier J \& Milgrom E 1989 Cloning and sequencing of porcine LH-hCG receptor cDNA: variants lacking transmembrane domain. Science 245 525-528.

Mangelsdorf DJ \& Evans RM 1995 The RXR heterodimers and orphan receptors. Cell 83 841-850.

Meyer TE \& Habener JF 1993 Cyclic adenosine $3^{\prime}, 5^{\prime}$-monophosphate response element binding protein (CREB) and related transcription-activating deoxyribonucleic acid-binding proteins. Endocrine Reviews 14 269-290.

Minegishi T, Karino S, Tano M, Ibuki Y \& Miyamoto K 1996 Regulation of midkine messenger ribonucleic acid levels in cultured rat granulosa cells. Biochemical and Biophysical Research Communications 229 799-805.

Mondschein JS, Smith SA \& Hammond JM 1990 Production of insulin-like growth factor binding proteins (IGFBPs) by porcine granulosa cells: identification of IGFBP-2 and -3 and regulation by hormones and growth factors. Endocrinology 127 2298-2306.

Oberg KC \& Carpenter G 1989 EGF-induced PGE2 release is synergistically enhanced in retinoic acid treated rat lung cells. Biochemical and Biophysical Research Communications 162 1515-1521.

Paterno GD, Gillespie LL, Julien JP \& Skup D 1997 Regulation of neurofilament L, M and $\mathrm{H}$ gene expression during retinoic acid-induced neural differentiation of P19 embryonal carcinoma cells. Brain Research 49 247-254. 
Safonova I, Davimont C, Amri E, Grimaldi P, Aihaud G, Reichert U \& Shroot B 1994 Retinoids are positive effectors of adipose differentiation. Molecular and Cellular Endocrinology 104 201-211.

Schule R, Rangarajan P, Yang N, Kliewer S, Ransone LJ, Bolado J, Verma IM \& Evans RM 1991 Retinoic acid is a negative regulator of $\mathrm{AP}-1$ responsive genes. PNAS $\mathbf{8 8}$ 6092-6096.

Sheng M \& Greenberg ME 1990 The regulation and function of c-fos and other immediate early genes in the nervous system. Neuron 4 477-485.

Spanjaard RA, Ikeda M, Lee PJ, Charpentier B, Chin WW \& Eberlein TJ 1997 Specific activation of retinoic acid receptors (RARs) and retinoid $\mathrm{X}$ receptors reveals a unique role for RARg in induction of differentiation and apoptosis of S91 melanoma cells. Fournal of Biological Chemistry 272 18990-18999.
Suyawan A \& Hu CY 1997 Effect of retinoic acid on differentiation of cultured pig preadipocytes. Fournal of Animal Science 75 112-117.

Thiele CJ, Cohen PS \& Israel MA 1988 Regulation of c-myb expression in human neuroblastoma cells during retinoic acid-induced differentiation. Molecular and Cellular Biology $\mathbf{8}$ 1677-1683.

Yen A, Cherington V, Schaffhausen B, Marks K \& Varvayanis S 1999 Transformation-defective polyoma middle $\mathrm{T}$ antigen mutants defective in PLCg, PI-3, or src kinase activation enhance ERK2 activation and promote retinoic acid-induced cell differentiation like wild-type middle. Experimental Cell Research 248 538-551.

REVISED MANUSCRIPT RECEIVED 10 February 2000 